紹介

\title{
医療面接に扔ける対象者のニーズの把握に関する 学生の能力とその学習について
}

\author{
Students Ability and Learning Method for Understanding Patients' Needs \\ in Medical Interviews
}

\begin{abstract}
中平 剛志 ${ }^{1)}$ 越智 久雄 ${ }^{1)}$ 今井 公一 ${ }^{2)}$ 笠原 弘樹 ${ }^{1)}$ 宗野 寿恵 ${ }^{1)}$

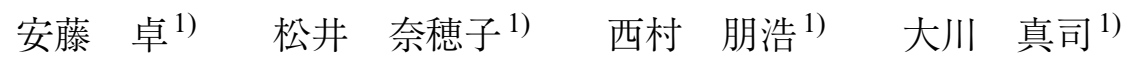


NAOKO MATSUI ${ }^{1)}$, TOMOHIRO NISHIMURA ${ }^{1)}$, SHINJI OHKAWA ${ }^{1)}$

1) Department of Physical Therapy, Osaka College of Rehabilitation: 1-17-3 Temma, Kita-ku, Osaka 530-0043, Japan. TEL+816-6354-0091E-mail: takeshi.nakahira@ocr.ac.jp

${ }^{2)}$ Department of Rehabilitation Science, Osaka Health Science University
\end{abstract}

Rigakuryoho Kagaku 30(6): 999-1003, 2015. Submitted Jun. 12, 2015. Accepted Jul. 20, 2015.

ABSTRACT: [Purpose] The purpose of this research was to clarify students' ability to understand patients' needs in a medical interview, and to investigate the learning method. [Subjects] The subjects were 15 second-year physical therapy students. [Methods] Using an Objective Structured Clinical Examination, the contents of a medical interview were divided into five elements: introduction, chief complaint, current ADL, past ADL, and demands. The time spent on each was measured and calculated as a ratio of the whole. We analyzed the scope and intent of questions about future daily living. [Results] The time required for the entire medical interview averaged 10.8 minutes. All 15 students conducted the interview covering the five elements, and the ratio of the time spent on current ADL was large. The questioning focused on future daily living and work, and confirmation of information obtained in advance was the main objective. [Conclusion] Formally carrying out a medical interview is a standard objective of school education, and in order for students to master the ability to understand individual patients' needs, it is important for them to learn through the experience of clinical practice.

Key words: Objective Structured Clinical Examination (OSCE), medical interview, needs

要旨：〔目的〕学生が医療面接でニーズを把握する能力を明らかにし, 学習方法を検討する.〔対象〕理学療法学科第 2 学年 15 名とした。〔方法〕客観的臨床能力試験を用いて医療面接の内容を導入, 訴え, 現在の ADL, 以前の ADL,

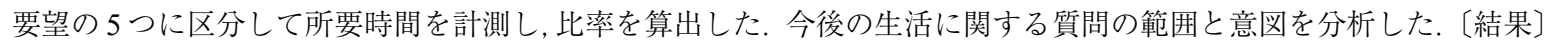
面接全体の所要時間は平均 10.8 分であった. 15 名全員が 5 つの要素を含んだ質問を実施し，現在の ADLの比率が 大きかった，質問の範囲は今後の日常生活や仕事に主眼を置くが，事前に得た情報を再度確認する意図が主であった 〔結語〕形式的に医療面接を実施することが学内の到達点であり, 学生が対象者個々のニーズを把握する能力を習得 するためには臨床実習の経験を通じた学習が重要である.

キーワード : 客観的臨床能力試験, 医療面接, ニーズ

1) 大阪リハビリテーション専門学校 理学療法学科: 大阪府大阪市北区天満 1 丁目 17 番 3 号 ( ₹ 530-0043) TEL 06-6354-0091

2) 大阪保健医療大学 保健医療学部リハビリテーション学科 理学療法学専攻 


\section{I.はじめに}

理学療法評価の過程では, 診療録や他部門からの情報 収集と併せて，医療面接により対象者から直接収集した 情報をもとに仮説的な障がい像を想起し, さらに検査・ 測定，動作観察などの結果を踏まえてその詳細が明らか にされていく 1-4)。この医療面接により収集された情報 の中で, 重要であるのは対象者本人の主訴や要望であ り ${ }^{5)}$ ，これらを把握できる過程は直接対象者と対面する 医療面接以外に無く，その重要性を意図して収集すべき ものである。また，主訴や要望はリハビリテーション ゴールを設定する際に重要な因子となりうるが 6)，学生 にとっては対象者個々のニーズを把握し，具体的なゴー ルを考察するという難易度の高い課題の一つである。

医学教育では, 1990 年代から客観的臨床能力試験（以 下，OSCE）が導入され7), 医療面接の技能の習得にお ける模擬患者を用いた教育の効果 ${ }^{8-12)}$ p OSCEに㧍け る評価の妥当性や問題点 13-16) について検証した報告が 多数みられる。一方, 理学療法教育では, 2000 年以降 にOSCEが導入されるようになり，理学療法過程の教 育に対する評価手段として定着してきた17-20)。先行研 究では, 学生が習得すべき医療面接の技能について, OSCEの結果を用いて検証された報告 21,22) は散見され るが，対象者との信頼関係を構築する為の態度面や情報 収集としての基本的な技法に観点があり，対象者のニー ズの把握を目的とした観点から分析し，その学習過程に ついて言及した報告は見当たらない。そこで，大阪り八 ビリテーション専門学校で用いられている OSCE の結 果を用いて，実施された医療面接の内容を分析し，ニー ズの把握に関わる学生の行動について検証した．対象と なる学生は臨床実習前の段階であり, この検証により ニーズの把握に関する学内教育の成果とその役割を明ら かにし, 効果的な指導方法検討の一助となることを期待 するものである。

\section{II. 対象と方法}

対象は理学療法学科第 2 学年 38 名に対して実施され た OSCE の内，同一内容の模擬患者を対象とした 15 名 (男性 12 名, 女性 3 名, 平均年齢 $29.4 \pm 5.4$ 歳) である. 試験は事前の症例提示 (30 分), 評価の実施 (25 分),
結果の報告（5 分），質疑応答（15 分）の手順で実施し た（表 1)。な押，評価の実施の 25 分は診療報酬一単位 を想定した．模擬患者はOSCEの目的を理解し協力を 得られた理学療法士が演じた。設定内容は，65歳男性 で診断名は右中大脳動脈閉塞 (左片麻㾝), OSCE で学 生が担当する時点は発症後 3 力月，入院後 3 力月経過時 点で初回面接を受けたものとした． 2 人の娘が独立した 後は妻と 2 人暮らし. 3 力月後に長女に初孫が産まれる 予定があり，これを機に長女夫婦と同居する計画があり 楽しみにしていた。一人でしっかり歩けるようになりた いと要望があることとした．また，今後の生活に関する 質問に対する演じ方として，第一段階で学生の質問が抽 象的である場合は夫婦 2 人での生活が目標であると発言 し，第二段階で学生の質問が具体的に展開し，潜在的な 気持ちを聞き出されたと感じた場合には長女との同居に 関する願望を語ってもらうこととした。

分析対象は自己紹介を開始した場面から一連の質問が 終了するまでとし，記録した映像と音声を用いて医療面 接全体の所要時間, 質問内容の構成と比率, 学生の質問 内容に対する検討を行うこととした。

分析方法は，映像より所要時間を計測し，次に医療面 接の音声記録を文字記録に起こし，著者を含む 2 名の教 員で内容分析を行うこととした，質問内容の構成と比率 については, 学生が模擬患者に質問した内容を $5 つ の$ 要 素，すなわち自己紹介およびオリエンテーション等の面 接の導入，患者の訴えおよび症状，現在の日常生活活動

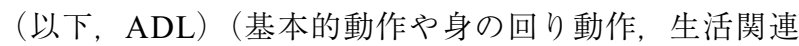
動作に関する質問), 以前の ADL および社会的情報, 今後の生活に関する見通しおよび本人の要望，に関する 質問に区分し，要素の所要時間を面接全体の所要時間に 対する比として算出した，また，学生の質問内容につい ては，今後の生活に関する質問に着目し，質問の範囲を 今後の日常生活（基本的動作や身の回り動作，生活関連 動作に関する質問），仕事（就業内容や雇用体制に関す る質問)，趣味の 3 つのカテゴリーに分類した。ささらに 日常生活に関する質問の意図を事実確認と追求・推測の 2 つのカテゴリーに分類した。

研究の倫理的配慮として, OSCE 実施前に学生に対し て映像と音声を記録することを予め説明し，全員から書 面による同意を得た。

表 1 OSCE の実施概要

\begin{tabular}{lll}
\hline 手順 & 設定時間 & 内容 \\
\hline 症例提示 & 30 分間 & 事前情報から評価を計画 \\
評価の実施 & 25 分間 & 医療面接, 検査・測定, 動作観察を実施 \\
報告 & 5 分間 & 障がい像, 目標設定, 治療プログラムについて報告 \\
質疑応答 & 15 分間 & 試験官と質疑応答 \\
\hline
\end{tabular}




\section{III. 結 果}

医療面接全体の所要時間は平均 10.8 分（7～15.5 分） であった，質問内容の構成は, 対象者の 15 名全員が 5 つの要素を含んで扔り, 各要素に扔ける所要時間と比率 の 15 名の平均値は, 面接の導入が 1.3 分 $(12.6 \%)$, 患 者の訴えや症状が 1.7 分 (15.8\%), 現在の ADL が 3.6 分 $(32.9 \%)$, 以前の ADL や社会的情報が 2.4 分 (22.5\%), 今後の生活に関する見通しや本人の要望が 1.8 分（16.2\%）であった（表 2)。質問の範囲の該当す るカテゴリーは, 15 名中, 最も多い 10 名が今後の日常 生活と仕事, 4 名が仕事と趣味, 1 名が今後の日常生活 と仕事と趣味であった，質問の意図は日常生活に関する 発話があった 11 名中, 10 名が事実確認, 1 名が追求. 推測であった（表 3).

\section{IV. 考 察}

我々が実施している OSCEでは模擬患者に対する評 価の実施時間を 25 分と設定されているが，学生には評 価の実施後に障がい像や目標設定，治療プログラム立案 についての報告が課されている。したがって，評価の実 施に扔いて医療面接, 検査・測定, 動作観察の項目を全 て実施する必要性が高く，さらには実施時間の配分につ いても学生が判断しなければならない. 表 2 に示す結果 から，15 名全員が医療面接を実施していることから, 事前に提示された情報以外に, 医療面接により収集しな
ければならない情報があることを理解していることが明 らかである。また，面接内容については 15 名全員が全 ての要素に触れていた。このことから, 理学療法評価の 過程に扔いて医療面接の必要性を認識し, かつ対象の評 価にあたっては，面接の導入から始まり，患者の訴えお よび症状，現在の ADL，以前の ADL 拉よび社会的情報， 今後の生活に関する見通し，本人の要望など， 5 つの要 素すべての情報が必要であることを認識した上で, 意図 のある行動を行っているものと理解できる。すなわち, 形式的に医療面接を実施できることが現段階に扔ける習 得可能な段階であることがいえる。

次に各要素の比率をみると, 全員が自己紹介やオリエ ンテーションなど導入部分を欠いていないことは, 初回 面接という設定であることを考慮すると好ましい結果で あると考えられる。また，最も時間配分の大きかったの は現在の ADL に関する質問であり，ADLに重点を置 いた面接となっていた点が特徽的である.

音声記録の分析によれば，模擬患者本人に対して入院 中の一日の生活状況を細部にまで聴取する場面や，理学 療法に抢ける歩行練習の状況を聴取する場面が多く認め られた。本来医療面接にあたっては，対象者本人から聴 取することで把握可能な情報と, 診療録や他部門からの 情報収集で把握可能な項目を判別して, 意図的に質問内 容や時間配分を選択しているが，学生にとってはその判 断は難しく, 全ての項目を患者本人から聴取しょうとす る傾向があるものと考えられる。

次に，今後の生活に関する学生の質問内容についてみ

表 2 医療面接の所要時間および比率

\begin{tabular}{|c|c|c|c|c|c|c|c|c|c|c|c|}
\hline \multirow{2}{*}{$\begin{array}{l}\text { 学生 } \\
\text { 番号 }\end{array}$} & \multirow{2}{*}{$\begin{array}{c}\text { 面接全体の } \\
\text { 所要時間 } \\
\text { (分) }\end{array}$} & \multicolumn{2}{|c|}{ 面接の導入 } & \multicolumn{2}{|c|}{ 訴えや症状 } & \multicolumn{2}{|c|}{ 現在の ADL } & \multicolumn{2}{|c|}{$\begin{array}{c}\text { 以前の ADL や } \\
\text { 社会的情報 }\end{array}$} & \multicolumn{2}{|c|}{ 今後の生活や要望 } \\
\hline & & $\begin{array}{c}\text { 所要時間 } \\
\text { (分) }\end{array}$ & $\begin{array}{l}\text { 比率 } \\
(\%)\end{array}$ & $\begin{array}{c}\text { 所要時間 } \\
\text { (分) }\end{array}$ & $\begin{array}{l}\text { 比率 } \\
(\%)\end{array}$ & $\begin{array}{c}\text { 所要時間 } \\
\text { (分) }\end{array}$ & $\begin{array}{l}\text { 比率 } \\
(\%)\end{array}$ & $\begin{array}{c}\text { 所要時間 } \\
\text { (分) }\end{array}$ & $\begin{array}{l}\text { 比率 } \\
(\%)\end{array}$ & $\begin{array}{l}\text { 所要時間 } \\
\text { (分) }\end{array}$ & $\begin{array}{l}\text { 比率 } \\
(\%)\end{array}$ \\
\hline 1 & 11.3 & 1.8 & 15.9 & 1.2 & 10.5 & 5.2 & 46.1 & 2.8 & 24.4 & 0.4 & 3.1 \\
\hline 2 & 15.5 & 1.7 & 10.8 & 1.5 & 9.7 & 5.8 & 37.6 & 2.8 & 17.7 & 3.8 & 24.2 \\
\hline 3 & 15.0 & 0.9 & 5.8 & 1.0 & 6.8 & 3.5 & 23.4 & 6.2 & 41.4 & 3.4 & 22.7 \\
\hline 4 & 9.2 & 1.2 & 13.1 & 0.9 & 10.0 & 3.9 & 42.4 & 1.7 & 18.9 & 1.4 & 15.6 \\
\hline 5 & 10.9 & 0.9 & 8.5 & 1.7 & 15.6 & 3.1 & 28.2 & 2.6 & 24.1 & 2.6 & 23.5 \\
\hline 6 & 10.2 & 1.3 & 12.4 & 1.2 & 11.8 & 4.9 & 47.9 & 2.0 & 19.6 & 0.9 & 8.3 \\
\hline 7 & 9.8 & 1.2 & 12.2 & 2.4 & 24.1 & 3.6 & 36.8 & 0.5 & 5.1 & 2.2 & 21.9 \\
\hline 8 & 10.7 & 1.6 & 15.1 & 2.0 & 18.6 & 2.4 & 22.5 & 4.0 & 37.4 & 0.7 & 6.4 \\
\hline 9 & 9.3 & 1.4 & 14.9 & 1.1 & 12.2 & 2.3 & 24.6 & 1.9 & 20.3 & 2.6 & 28.1 \\
\hline 10 & 7.6 & 1.0 & 13.1 & 1.4 & 17.7 & 2.1 & 27.9 & 1.5 & 19.4 & 1.7 & 21.8 \\
\hline 11 & 7.0 & 1.0 & 14.3 & 0.9 & 13.1 & 2.3 & 32.1 & 2.4 & 34.0 & 0.5 & 6.4 \\
\hline 12 & 10.3 & 1.6 & 15.4 & 1.1 & 10.6 & 3.8 & 37.4 & 2.9 & 27.8 & 0.9 & 8.8 \\
\hline 13 & 9.4 & 1.4 & 14.9 & 2.7 & 29.1 & 1.4 & 14.4 & 2.2 & 23.0 & 1.8 & 18.6 \\
\hline 14 & 11.1 & 1.2 & 10.3 & 2.7 & 24.0 & 3.8 & 34.3 & 1.5 & 13.0 & 2.1 & 18.4 \\
\hline 15 & 14.9 & 1.9 & 12.8 & 3.5 & 23.7 & 5.7 & 38.0 & 1.6 & 10.7 & 2.2 & 14.7 \\
\hline 平均值 & 10.8 & 1.3 & 12.6 & 1.7 & 15.8 & 3.6 & 32.9 & 2.4 & 22.5 & 1.8 & 16.2 \\
\hline
\end{tabular}


表 3 今後の生活に関する質問内容

\begin{tabular}{lc}
\hline 質問の範囲 & 該当人数 $($ 名 $)$ \\
\hline 日常生活と仕事 & 10 \\
仕事と趣味 & 4 \\
日常生活と仕事と趣味 & 1 \\
\hline 質問の意図 & 該当人数 $($ 名 $)$ \\
\hline 事実確認 & 10 \\
追求・推測 & 1 \\
\hline
\end{tabular}

ると, 15 名中 4 名は今後の日常生活ではなく, 仕事や 趣味に重点を置いていることが興味深い。また，日常生 活に主眼を置く他の 11 名についても, その質問の意図 は事前情報として既に知り得ている家屋構造, 家族構成, 妻の介護力などの社会的情報に関するものであり，対象 者本人からの直接聴取による事実確認が多く, 事前情報 にはない具体的な生活状況, キーパーソンとなる娘の存 在や同居の可能性などについて模索しながらの質問は 1 名のみに認められた。これらの点は学内教育におけるこ の時期の学生の到達点としての限界とも考えられる。

ここでニーズの把握に関する理学療法士としての思考 モデルの一例を提示する. 初めに, 理学療法士は診療録 や他部門から得た事前情報から，人物像を想起する。次 に, 疾患や障がいの一般的な回復過程の知識を用いて仮 の予後予測を行うが，現時点より自立度が向上する場合 と，現状維持もしくは低下する場合を仮定する。そして 目標設定を立案するが, 解決すべき優先課題として身の 回り動作を中心とする日常生活の営みに主眼を置くこと が常である。そして目標を仮定した上で，医療面接で聴 取した対象者本人の要望と照らし合わせて検討すること が重要である。このような理学療法士による思考の一例 をふまえて，学生による思考の典型例を検討してみると， 一つ目には仮の予後予測に関する思考が困難で, 聴取し た患者の要望に依存する点が特徵的である。つまり患者 が発した言葉が，直接ニーズに反映される思考である。 こうした思考の成因について考えると, 一般的な疾患の 知識を持ち合わせていたとしても，障がいの回復の予測 には繋がらず，学生にとっては思考の難しい課題である と推察される。二目には患者の活動に主眼を置かず, 参加からニーズを導き出すことが特徵的である。つまり 身の回り動作を中心とする日常生活が自立することを重 要視せず, 生活関連動作や趣味, 仕事など社会的な営み にまで一気に飛躍してしまう思考である。このような思 考の成因について考えると, 学生は自身の健康的な日常 生活を振り返り，その生活像についてイメージを深める ことは可能であるが, 障がいを持ちながら日常生活を営 むことを想像することは，現段階では容易ではなく，ま た, 活動と参加レベルとの具体的な関連性を思考するこ とについて,さらに経験が必要であるものと考えられ
る.

理学療法評価における対象者のニーズを把握する思考 過程においては，形式的な思考のみでは通用せず，対象 者個々の要望を聴き，個人因子や環境因子に照らし合わ せ根拠を持ちながら臨機応変な思考が求められる。この ような思考の習得を学習目標として, 学内教育において は模擬症例を用いた演習など様々な工夫を実践している が, 今回示した結果は学内教育における現段階での成果 であると同時に, 学生の到達点の限界を示唆するものと も考えられる。したがって，学内教育ではこうした思考 のために必要な知識，すなわち基本的な動作能力の予後 予測に関する知識などの習得を第一の学習目標とし, そ れらの知識を思考に耐えうるレベルにまで高めるために OSCE を用いた学習が必要である。ささらは，臨床現場 で対象者との関わりを通じて，障がいを持ちながら日常 生活を営む方々と直接関わりながら, 生活像を具体的に イメージして思考することを繰り返し経験する学習が必 要である.

以上のように，今回の結果は各々の段階での学習目標 のあり方に対して一定の示唆を与えるものであり，理学 療法士にとって重要なニーズの把握に関する能力は, 学 内と臨床実習による継続的な教育の連携によって習得さ れるものであると結論できる.

\section{引用文献}

1) 潮見泰藏, 下田信明:リハビリテーション基礎評価学. 羊土社, 東京, 2014, pp33-38.

2) 岩倉博光, 松澤 正: 理学療法評価法第 3 版. 金原出版, 東京, 1997, pp1-8.

3) 臼田 滋: ビジュアルレクチャー理学療法基礎評価学. 医 歯薬出版, 東京, 2014, pp20-29.

4) 嶋田智明: 理学療法評価一そのクリニカルアプローチ. メディ カルプレス, 東京, 1997, pp56-59.

5) 南郷栄秀: 医療面接の基本と客観的臨床能力試験 (OSCE). 臨床評価, 2013, 40: 395-400.

6)上田 敏：リハビリテーションを考える. 青木書店, 東京, 1983, pp171-181.

7) 伴信太郎: 客観的臨床能力試験臨床能力の新しい評価法定. 医学教育, 1995, 26: 157-163.

8) 北川元二, 伴信太郎, 島田康宏：OSCEの医療面接に扮け る学生模擬患者の試み. 医学教育, 2000, 31:247-254.

9) 坂本敦子, 犬伏美雪, 小宮良輔・他：医学生が標準模擬 患者として参加する医療面接実習. 医学教育， 2000，31: 199-202.

10) 磯部光章, 坂本敦子, 犬伏美雪・他：クリニカル・クラー クシップに扔ける医療面接実習. 医学教育, 2001，32: 47-52.

11）舛形 尚, 岡田宏基, 余島侑子 - 他 : 共用試験 OSCE後の 臨床実習における模擬患者による医療面接実習の意義と問 題点. 医学教育, 2009, 40: 175-179.

12）原田芳巳, 平山陽示, 和久保佳奈・他：医療面接実習では 教員の臨床での体験談－学生同士の討論が期待されている 
一教員からのフィードバックに対する評価の多面的解析に もとづく教員マニュアルの効果の検討一. 医学教育, 2015, 46: 53-62.

13) 斎藤清二, 松井三枝, 牛 麗沙 ·他 : 医療面接技能の客観 的臨床能力試験 (OSCE) による評価一特に認知行動特性と の関連について一. 医学教育, 2000, 31:213-219.

14) 村上純子, 竹中秀夫, 堀越 永 ·他：客観的臨床能力試験 (OSCE) に打ける医療面接評価の問題点一評価の客観性を より高めるために一。医学教育, 2001, 32: 231-237.

15) 福本陽平, 村上不二夫, 今井一彰・他 : 客観的臨床能力試 験での医療面接における評価の差の問題について. 医学教育 2002, 33: 209-214.

16) 福本陽平, 村上不二夫, 小早川節・他：医療面接に扔ける 教員と模擬患者による学生評価について一山口大学医学部 における 3 年間の検討一。医学教育, 2004, 35: 229-234.

17) 山路雄彦, 渡邊 純, 浅川康吉 - 他 : 理学療法教育におけ
る客観的臨床能力試験 (OSCE) の開発と試行. 理学療法学, 2004, 31(6): 348-358.

18) 森田正治, 清水和代, 宮㠃至恵 - 他 : 理学療法学教育に おけるOSCEの試み。理学療法ジャーナル, 2006, 40(3): 233-240.

19) 佐藤 仁: 模擬患者を導入した授業の試み. 理学療法科学, 2008, 23(1): 115-119.

20) 前島 洋, 川井伸夫, 高田治実: 理学療法学教育における 客観的臨床能力試験 (OSCE) 導入の課題と実践. 帝京科学 大学紀要, 2013, 9: 81-88.

21) 岡田啓太, 工藤慎太郎, 小松真一・他：OSCEにおける試 験官と模擬患者による評価の関連性. 理学療法科学, 2012, 27(4): 367-371.

22) 平山朋子, 松下佳代, 西村 敦：OSCEリフレクション法 の有効性一 2 年次 OSCE（医療面接）での学生の学びの分析 を通して一．医学教育, 2013, 44(6): 387-396. 